\title{
Application of Taiwan's Human Rights-Themed Cultural Assets and Spatial Information
}

\author{
Shuhui Lin \\ Department of Taiwan Culture, Languages and Literature, National Taiwan Normal University, Taipei, Taiwan \\ Correspondence should be addressed to Shuhui Lin; siokhui@gapps.ntnu.edu.tw
}

Received 6 December 2019; Revised 18 February 2020; Accepted 3 April 2020; Published 28 May 2020

Guest Editor: Shu-Heng Chen

Copyright ( 2020 Shuhui Lin. This is an open access article distributed under the Creative Commons Attribution License, which permits unrestricted use, distribution, and reproduction in any medium, provided the original work is properly cited.

Cultural assets preserve the traces of people's life history around the world. With an understanding of the historical context and meaning of cultural assets, people would cherish their value and then adopt appropriate cultural resource preservation strategies. Human rights as the universal value refer to the inalienable and basic rights of human beings. This article uses the National Cultural Assets Network to query Taiwan's human rights-themed cultural assets, and I apply the spatial information technology of the DocuSky digital humanities academic research platform to draw the maps with GIS and visualization tools. Also, I apply spatial information to the academic research of human rights-themed cultural assets, aiming to deepen local cultural identity and unveiling that human studies influence spatial practice. Tourism is an important experience economy. Based on the value of Taiwan's human rights-themed cultural assets, I plan to guide the human rights journey in Taipei to share Taiwan's experience of happiness with the world, as well.

\section{Introduction}

In recent years, the meaning of cultural and spatial information has been found out to explore the local cultural context and as well as the way to see the world. Calling the sense of locale from ancient to modern to attract the attention of international tourists has become an alternative way to promote Taiwanese culture. Due to the academic exchange and with the help of the visiting scholars, I personally experienced the Cultural Tour of Boston in the Freedom Trail. The tourists listened to the guides, who dressed in traditional costumes introduced the main scenes, and there were a number of visitors who made an on-thespot inspection along the route paved by red bricks. A flock of tourists across the world visited the Anne Frank House in Amsterdam, Netherlands, and the United States Holocaust Memorial Museum, witnessing the historical significance and trauma as shown in the manuscript of Anne Diary and the museum display.

The landscape is shaped by the life experience of the people, and it is an ideographic system. Geography and literature are both the writings about place and space, and both are ideographic processes that impose meaning on a place in social media. With time flowing, the cultural assets preserve the traces of people's life history around the world and serve as the precious treasure of human society and culture in the world. Taiwan experienced multiple colonization, thus facing the problems of deep cultural grafting and transferring. Looking back at Taiwanese cultural tour activities, I find that they more often did not focus on individual historical site introduction; however, guided tours with themes and concepts can better highlight the ideological implication of Taiwan's diachronic character and reflect the universal value of the theme.

The identification principles of the world cultural heritage are mainly based on the universal value, rarity, and protection priority. According to the Law on the Preservation of Cultural Assets, which was amended and passed on July 12, 2016, the categories of monuments and historical sites were added, and cultural asset preservation education through the school education system was also implemented. The special measures for the cultural assets of indigenous peoples were specified, and the preservation of cultural assets of diverse ethnic groups was emphasized $[1,2]$. Legal norms 
are important all right, but there are more fundamental works to do to make people value their cultural assets. Accordingly, first people must be helped to recognize and love their culture. So, the study of space humanities becomes more urgent. What human rights-themed cultural assets do Taiwan own? How to apply spatial information to guided tours of human rights-themed cultural assets? This manuscript combines the cross-domain application of spatial information, hoping to present the theme of tangible cultural assets, highlighting it in Taiwanese culture.

\section{Related Literature}

Regarding the conceptualization of space, the French scholar Lefebvre's concepts of spatial practice, representation of space, and representational spaces are quite canonic. Spatial practice is to reflect the close connection between daily reality, affairs, and urban reality in the perceived space, involving various functional spaces from architecture to large-scale urban facilities. Representation of space involves conceptualized and conceived space, and furthermore, it is a space in which scientists, planners, and technical bureaucrats are engaged. As the dominant space in lifestyle, it identifies life and perception with concepts. The representational space is the space that is directly used for life through the related images and symbols. It is the space of the occupants and users, tending to be a system of coherent, nonverbal symbols and signs [3]. Wang pointed out that "place" is a meaningful location, a significant space created by human beings, who are attached to it in some way. The space to which the city refers is carved out by the interaction among specific institutions with historical and geographical features, social relations of production and reproduction, governmental actions, forms of communication, and media $[4,5]$. Although the concept of space can be reflected in different levels, the texts related to cultural assets represent the process of so-called urban cultural changes, as well as the impact that such developments produced.

This manuscript points out that when the space constructed by cultural assets is accompanied by the accumulation of special experience, historical context, and a sense of identity, the meaning of place comes into being. These highly conceivable features and the meaningful realization about the place turn out to be people's emotional attachment to Taiwan, and thus express the meaning of locality. For the city dweller, each city is imaginable and is of consciousness associated with the atmosphere and taste of the environment, instead of a vague concept [6]. For example, literature contains rich social customs and habits, language and voice, agricultural and fishery products, dietary habits, landscapes, vegetation, residents' emotions, history, and culture, and other assets accumulated by conventional wisdom Literary works are impressively characteristic of local colors. I collect texts about cultural assets and read articles about imagery depiction in different places, which describes various spatial characteristics, impressions, and feelings. Also, they were integrated with geographic information systems to represent the memories and atmosphere of cultural assets in that era.
Backtracking to the maps drawn in the Japanese colonial period, such as the Taiwan Fort Map with a proportion of one to 20,000 in 1904 and the Taiwan Topographic Map with a proportion of one to 25,000 in 1926 , it is seen that they mostly implied the planning, decision-making and management, statistics, investigation, and research about Taiwan, which had been conducted in the Japanese Empire, and these data are mostly based on maps. Therefore, the contents of the maps are all-encompassing, including natural resources, agriculture, forestry and fishery, urban planning, transportation, and tourism. A map is a representation of the distribution of surface space. Each map is the product coded by the drafter. In the coding process, the drafter inevitably incorporates his personal perspective $[7,8]$. In recent years, scholars and some professional drafters have rewatched Taiwan from an alternative angle, and thus the maps have showcased a new perspective [9]. These examples are inclusive of Taiwan's proximity to Southeast Asia, its relative position with China, the value of eastern Taiwan, and how to ruminate Taiwan's interaction with the world. This manuscript is inspired in the remapping process, and the relevant maps of human rights theme present the association between Taiwan's cultural assets and social pulsations [10-12].

\section{Main Data Sources}

In the 19th century, European countries had started to formulate laws on the protection of historic sites and buildings on the cultural attractions and historical monuments constructed by the interaction between people and space. In 1922 (Taisho 11), the Governor's Office issued the Decree No. 521 (Act on the Preservation of Natural and Historical Monuments in Taiwan) and then designated prehistoric culture from the Qing Dynasty rule to the Japanese occupation and other cultural relics from different periods. Also, the content mainly focused on diversified cultural attraction resources. In the early postwar period, maintenance work was mainly made by craftsmen, and later the governmental authorities and folk craftsmen worked together to deal with the cultural assets. The Law on the Preservation of Cultural Assets was promulgated on May 26, 1982. Since then, it has been formulated and amended and has been the controversial social issue because of the preservation of historic sites. The broadly defined antiquities factors of prewar China and the local cultural asset elements of postwar Taiwan should be understood and blended with each other, creating a harmonization and transformation in concepts and keeping updating and adjusting the connotation of the prewar Cultural Assets Preservation Law to make it meet the local cultural and social needs of postwar Taiwan. This process of shaping the legal system means that the trajectory of the national identity axis flipped in the past [13]. As for the latest revision of the Cultural Assets Preservation Law in 2016, the so-called cultural assets refer to constructions with cultural values in history, art, and science and are designated or registered as tangible and intangible cultural assets. Among them, tangible cultural assets can be divided into historic sites, historical buildings, memorial buildings, settlement buildings, archeological sites, historical 
sites, and cultural scenes [14]. The designation criteria for historic relics, repeal conditions, procedures for application and examination, assistance, and other measures to be followed shall be determined by the central competent authority [15]. Monuments include buildings and ancillary facilities with historical, cultural, and artistic values built by humans for their daily needs.

The concept of cultural scenery was proposed at the 16th session of the UNESCO World Heritage Committee in Santa $\mathrm{Fe}$, New Mexico, in December 1992, and was included in the World Heritage List. In the current society, the sustainable landscape maintains a positive social role associated with traditional lifestyles, and its own evolution is still ongoing and witnessing historical evidence of evolution and development. Relevant cultural landscapes are characterized by their connection with natural factors, religion, art, or culture, rather than cultural evidence.

This article uses the National Cultural Assets Network (https://nchdb.boch.gov.tw/) to inquire about human rightsrelated persons, events, eras, locations, and cultural assets in Taiwan and sort them in Table 1.

The memorial locations related to the theme of human rights include the activists' residences, working place, and grave yards. For example, Qiu Xian-chia Cemetery, Tang Techang Memorial Park, Yin Hai-kuang's Residence, and Fenglin Principal's Dream Factory. Landscape was associated with human rights, as well. Take Wufeng Lin Family Mansion and Garden, for example. It was not only Lin's residence, a then gathering place of talents, but also the meeting place for literary men at the Taiwanese Culture Association.

The Qing Tanshui Camp had been established for the then authorities, who intended to contain aborigines and criminal gangs, chasing them out of the mountain after the Zhu Yi-kuei Event. The landscape witnessed the ruler's oppression and antihuman rights. Jen-Her Temple in Er-Lin was located where farmers gathered at the Mazu Temple (current Jen-Her Temple) and decided to organize "the group of farmers." As the protest had been hindered, many participants were put in jail. However, after that, the groups of farmers across Taiwan followed suit, lodging petitions, and holding mass protests. All of these were the historical events related to human rights. Other landscapes such as Remains of Taipei Prison Wall, Chiayi's Old Prison, Tainan District Court, and Taiwan Provincial Council Building showcased the historical development of Taiwanese human rights, as well.

At present, the practice of preserving cultural assets not only expands citizen participation, but also adds fresh categories such as monuments and historical sites to strengthen the connection between Taiwan's land and history. In addition, in the United Nations Conventions on World Cultural Heritage and Intangible Cultural Heritage, the definition of cultural asset classes and the principles of preservation have been described in the provisions of the bill, so that the preservation of Taiwan's cultural assets can be further in line with international standards. Because these monuments in Table 1 are mostly related to the spirit of freedom, representing the spirit of the age, the human rights-themed cultural assets are considered as the scope of research [16-22].

\section{Methodology}

In addition to the literature research method of collecting the outer background and text, the analysis of the collected cultural assets through geographic information system will help to represent the related context of cultural assets from the temporal axis and spatial dimensions. The main research methods are as follows.

4.1. Extensive Searching for Cultural Asset Classes by Database. In recent years, various institutions in Taiwan have collected Taiwanese historical materials through various channels, such as Taiwan postcards handed down from the Japanese rule period, old photos of diverse spots, ancient books, local chronicles, archaic documents, genealogies, rubbings from stone inscription, audiovisual materials, and digital video files of news [21,21]. These Taiwanese historical documents and audio-visual records are archived with digital technology. It is hoped that through the establishment of the Taiwan Memory system, the historical documents associated with Taiwan will be stored in a digital archive, and the establishment of interpretation data through digital objects will achieve the purpose of data sharing and reusing [22-24]. Also, through the wide reach of the Internet, it is possible to expand the reading and research of historical materials in Taiwan to every corner of Taiwan and the whole globe.

In researching Taiwan's cultural assets, it often takes time to collect texts scattered all over the place, as well as the various long-term historical materials accumulated for a long time $[25,26]$. If you use the database to search for related historical and historical files, you can save the time of searching for information and focus on the interpretation of the theme. However, the results of many databases searching often fail to show the relevant logic. If you do not know the context, when facing with complicated historical data, it is like needle hunting in the vast sea and makes people set back from the work. Many databases have functions such as Full Text retrieval and Metadata retrieval, providing humanities researchers with immediate and efficient assistance in the process of searching for references and interpreting historical data. Recently, some databases have been set up to provide subcategories of people's names, place names, ages, provenances, or word frequencies [24-30]. After categorizing the data, it really helps to inspire academic research. This manuscript uses the National Cultural Heritage Database Management System to screen human rights-related cultural assets in a thematic way. Also the form fields of the list are made according to type, administrative area, announcement number, announcement date, latitude, and longitude.

4.2. Application of Cultural Assets and Cartography. A landscape is a local surface of the Earth that we can deliberately view from a certain place. The landscape combines the physical topography of the local land (things that can be viewed) and the concept of vision (viewing modes). Scenery is a strong visual concept. In most of the definitions of scenery, the viewer is outside the scenery, which is the main difference 
TABLE 1: Human rights-themed cultural assets in Taiwan.

\begin{tabular}{|c|c|c|c|c|c|c|}
\hline Name & Category & $\begin{array}{l}\text { Administrative } \\
\text { division }\end{array}$ & $\begin{array}{c}\text { Code of } \\
\text { announcement }\end{array}$ & Date & $\begin{array}{l}\text { North } \\
\text { latitude }\end{array}$ & $\begin{array}{c}\text { East } \\
\text { longitude }\end{array}$ \\
\hline $\begin{array}{l}\text { Rose Historic Site-Tsai Jui-yueh } \\
\text { Dance Research Institute }\end{array}$ & Historic site & $\begin{array}{c}\text { Zhongshan Dist., } \\
\text { Taipei City }\end{array}$ & 8809036001 & $1999 / 12 / 31$ & 25.055801 & 121.521987 \\
\hline Remains of Taipei Prison Wall & Historic site & $\begin{array}{l}\text { Da'an Dist., Taipei } \\
\text { City }\end{array}$ & 8701538601 & $1998 / 3 / 25$ & 25.033938 & 121.526848 \\
\hline $\begin{array}{l}\text { Wufeng Lin Family Mansion } \\
\text { and Garden }\end{array}$ & Historic site & $\begin{array}{l}\text { Wufeng Dist., } \\
\text { Taichung City }\end{array}$ & 357272 & $1985 / 11 / 27$ & 24.060856 & 120.703193 \\
\hline $\begin{array}{l}\text { Jen-Her Temple, Er-Lin Cane } \\
\text { Farmer Group }\end{array}$ & Historic site & $\begin{array}{l}\text { Erlin Township, } \\
\text { Changhua County }\end{array}$ & 357272 & $1985 / 11 / 27$ & 23.899129 & 120.368114 \\
\hline Tang Te-chang Memorial Park & Historic site & $\begin{array}{l}\text { West Central Dist., } \\
\text { Tainan City }\end{array}$ & 09318507120 & $2004 / 4 / 30$ & 22.992603 & 120.205019 \\
\hline Wistaria House & Historic site & $\begin{array}{l}\text { Da'an Dist., Taipei } \\
\text { City } \\
\end{array}$ & 860567701 & $1997 / 7 / 23$ & 25.024631 & 121.534325 \\
\hline Hai-Kuang’s Residence & Historic site & $\begin{array}{l}\text { Da'an Dist., Taipei } \\
\text { City }\end{array}$ & 09304427300 & $2004 / 2 / 9$ & 25.024200 & 121.531994 \\
\hline $\begin{array}{l}\text { National Taiwan Normal } \\
\text { University }\end{array}$ & Historic site & $\begin{array}{l}\text { Da'an Dist., Taipei } \\
\text { City } \\
\end{array}$ & 09200513500 & $2003 / 8 / 12$ & 25.025458 & 121.527349 \\
\hline Qiu Xian-chia Cemetery & Historic site & Beitun Dist., Taichung & 0960147621 & $2007 / 7 / 13$ & 24.15997 & 120.758974 \\
\hline Chiayi's Old Prison & Historic site & East Dist., Chiayi City & 0940061286 & $2005 / 5 / 26$ & 23.486155 & 120.458667 \\
\hline $\begin{array}{l}\text { Strictly forbidden for artisans to } \\
\text { transcend private monuments }\end{array}$ & Historic site & $\begin{array}{l}\text { Meishan Township, } \\
\text { Chiayi County }\end{array}$ & 1030002735 & $2014 / 1 / 21$ & 23.486180 & 120.458687 \\
\hline Tainan District Court & Historic site & $\begin{array}{l}\text { West Central Dist., } \\
\text { Tainan City }\end{array}$ & $\begin{array}{c}921648, \\
10330114152\end{array}$ & $1991 / 4 / 19$ & 22.989654 & 120.201102 \\
\hline $\begin{array}{l}\text { Qing Dynasty Tamshui Camp } \\
\text { historic site }\end{array}$ & Historic site & $\begin{array}{l}\text { Changzhi Township, } \\
\text { Pingtung County }\end{array}$ & 10530101300 & $2016 / 03 / 14$ & 22.699449 & 120.538609 \\
\hline $\begin{array}{l}\text { Lanyang coastline military } \\
\text { barracks during the period of } \\
\text { martial law }\end{array}$ & $\begin{array}{l}\text { Historical } \\
\text { building }\end{array}$ & $\begin{array}{l}\text { Zhuangwei Township, } \\
\text { Yilan County }\end{array}$ & $1030001175 B$ & $2014 / 03 / 21$ & 24.74026 & 121.816805 \\
\hline $\begin{array}{l}\text { Fenglin principal's Dream } \\
\text { Factory }\end{array}$ & $\begin{array}{c}\text { Historical } \\
\text { building }\end{array}$ & $\begin{array}{l}\text { Fenglin Township, } \\
\text { Hualien County }\end{array}$ & $1020004845 \mathrm{~A}$ & $2013 / 01 / 10$ & 23.747602 & 121.450369 \\
\hline $\begin{array}{l}\text { Former Taiwan Provincial } \\
\text { Council Parliament Building, } \\
\text { Chaoqin hall, Parliament hall }\end{array}$ & Historic site & $\begin{array}{l}\text { Wufeng Dist., } \\
\text { Taichung City }\end{array}$ & 0970009208 & $2008 / 12 / 25$ & 24.053938 & 120.700203 \\
\hline $\begin{array}{l}\text { Jing-Mei White Terror } \\
\text { Memorial Park }\end{array}$ & $\begin{array}{l}\text { Historical } \\
\text { building }\end{array}$ & $\begin{array}{l}\text { Xindian Dist., New } \\
\text { Taipei }\end{array}$ & 0960011931 & $2007 / 12 / 12$ & 24.988133 & 121.532352 \\
\hline Cihlin Memorial Hall & $\begin{array}{l}\text { Historical } \\
\text { building }\end{array}$ & $\begin{array}{l}\text { Wujie Township, } \\
\text { Yilan County }\end{array}$ & 2990 & $2001 / 6 / 29$ & 24.708924 & 121.771214 \\
\hline $\begin{array}{l}\text { The original site of Kaohsiung } \\
\text { Service Office, Formosa } \\
\text { Magazine }\end{array}$ & $\begin{array}{l}\text { Historical } \\
\text { building }\end{array}$ & $\begin{array}{l}\text { Xinxing Dist., } \\
\text { Kaohsiung City }\end{array}$ & 0930020248 & $2004 / 4 / 9$ & 22.629483 & 120.301412 \\
\hline $\begin{array}{l}\text { Green Island White Terror } \\
\text { Memorial Park }\end{array}$ & $\begin{array}{l}\text { Cultural } \\
\text { landscape }\end{array}$ & $\begin{array}{l}\text { Ludao Township, } \\
\text { Taitung County }\end{array}$ & 1030010752 & $2014 / 1 / 27$ & 22.675208 & 121.496317 \\
\hline $\begin{array}{l}\text { Cemetery for political victims } \\
\text { during the period of martial law }\end{array}$ & $\begin{array}{c}\text { Cultural } \\
\text { landscape }\end{array}$ & $\begin{array}{l}\text { Xinyi Dist., Taipei } \\
\text { City }\end{array}$ & 10530402700 & $2016 / 6 / 4$ & 25.017529 & 121.564446 \\
\hline Ooshen Event Memorial Park & Historic site & $\begin{array}{l}\text { Ren'ai Township, } \\
\text { Nantou County }\end{array}$ & 1080148095 & 2019/7/11 & 24.02053 & 121.132593 \\
\hline $\begin{array}{l}\text { Jing-Mei White Terror } \\
\text { Memorial Park }\end{array}$ & $\begin{array}{c}\text { Historical } \\
\text { building }\end{array}$ & $\begin{array}{l}\text { Zhongzheng Dist., } \\
\text { Taipei City }\end{array}$ & 10230334500 & $2013 / 6 / 11$ & 25.032295 & 121.512074 \\
\hline Lo-Sheng Sanatorium & $\begin{array}{l}\text { Cultural } \\
\text { landscape } \\
\text { /historical } \\
\text { building }\end{array}$ & $\begin{array}{l}\text { Xinzhuang Dist., New } \\
\text { Taipei City }\end{array}$ & $\begin{array}{l}0980012321 / \\
09800123211\end{array}$ & $\begin{array}{l}2009 / 09 / 07 / \\
2009 / 09 / 07\end{array}$ & 25.022329 & 121.409269 \\
\hline $\begin{array}{l}\text { Chiang Wei-shui Memorial } \\
\text { Park }\end{array}$ & $\begin{array}{l}\text { Historical } \\
\text { building }\end{array}$ & $\begin{array}{l}\text { Xinyi Dist., Taipei } \\
\text { City }\end{array}$ & 10130329600 & $2012 / 6 / 1$ & 25.022114 & 121.560002 \\
\hline
\end{tabular}


TABle 1: Continued.

\begin{tabular}{|c|c|c|c|c|c|c|}
\hline Name & Category & $\begin{array}{l}\text { Administrative } \\
\text { division }\end{array}$ & $\begin{array}{c}\text { Code of } \\
\text { announcement }\end{array}$ & Date & $\begin{array}{l}\text { North } \\
\text { latitude }\end{array}$ & $\begin{array}{c}\text { East } \\
\text { longitude }\end{array}$ \\
\hline $\begin{array}{l}\text { National Taiwan Democracy } \\
\text { Memorial Hall }\end{array}$ & Historic site & $\begin{array}{c}\text { Zhongzheng Dist., } \\
\text { Taipei City } \\
\end{array}$ & $0963132772-1$ & $2007 / 11 / 9$ & 25.036845 & 121.518217 \\
\hline Legislature & Historic site & $\begin{array}{c}\text { Zhongzheng Dist., } \\
\text { Taipei City } \\
\end{array}$ & 10630459200 & $2017 / 6 / 12$ & 25.043900 & 121.519614 \\
\hline $\begin{array}{l}\text { Hong Lou At Kaohsiung } \\
\text { Municipal Kaohsiung Senior } \\
\text { High School }\end{array}$ & $\begin{array}{l}\text { Historical } \\
\text { building }\end{array}$ & $\begin{array}{l}\text { Sanmin Dist., } \\
\text { Kaohsiung City }\end{array}$ & 0920010663 & $2003 / 2 / 26$ & 22.638069 & 120.298005 \\
\hline The Ke Qi-hua House & $\begin{array}{c}\text { Historical } \\
\text { building }\end{array}$ & $\begin{array}{l}\text { Xinxing Dist., } \\
\text { Kaohsiung City }\end{array}$ & 0930020248 & $2004 / 4 / 9$ & 22.636088 & 120.30001 \\
\hline Remains of Yilan Prison door & $\begin{array}{c}\text { Historical } \\
\text { building }\end{array}$ & $\begin{array}{c}\text { Yilan City, Yilan } \\
\text { County }\end{array}$ & 2990 & $2001 / 6 / 29$ & 24.753885 & 121.751533 \\
\hline $\begin{array}{l}\text { Remains of Hualien Prison } \\
\text { Wall }\end{array}$ & Historic site & $\begin{array}{c}\text { Hualien City, Hualien } \\
\text { County }\end{array}$ & $1010020314 \mathrm{~A}$ & $2012 / 2 / 4$ & 23.98423 & 121.604485 \\
\hline The Monument of Tianzhong & $\begin{array}{c}\text { Historical } \\
\text { building }\end{array}$ & $\begin{array}{c}\text { Tianzhong Township, } \\
\text { Changhua County }\end{array}$ & $1010138438 \mathrm{C}$ & $2012 / 5 / 23$ & 23.851311 & 120.583393 \\
\hline The Yang Quan House & $\begin{array}{c}\text { Historical } \\
\text { building }\end{array}$ & $\begin{array}{l}\text { Changhua City, } \\
\text { Changhua County }\end{array}$ & $1070131006 \mathrm{~A}$ & $2018 / 4 / 18$ & 24.080784 & 120.542761 \\
\hline Former The Lin Zi Jin House & $\begin{array}{c}\text { Historical } \\
\text { building }\end{array}$ & $\begin{array}{l}\text { East Dist., Taichung } \\
\text { City }\end{array}$ & 10701338451 & $2018 / 7 / 2$ & 24.133626 & 120.688868 \\
\hline $\begin{array}{l}\text { Ooshen Event Mahpo Ancient } \\
\text { Battlefield -Butuc and Ancient } \\
\text { Trail }\end{array}$ & Historic site & $\begin{array}{l}\text { Ren'ai Township, } \\
\text { Nantou County }\end{array}$ & 1080148095 & $2019 / 7 / 11$ & 24.015990 & 121.188638 \\
\hline The Castle of Jianshi tapung & Historic site & $\begin{array}{l}\text { Jianshi Township, } \\
\text { Hsinchu County }\end{array}$ & 0950095754 & $2006 / 7 / 24$ & 24.692815 & 121.303584 \\
\hline
\end{tabular}

between scenery and place [31]. The link between spatial information and humanities research focuses on tracking and naming from the perspective of microobjects as well as exploring the significance of local historical moments. Objective data were used to collect maps and texts in a historical and scientific way and examine the location of cultural assets.

The DocuSky digital humanities academic research platform was applied, and the maps were drawn with "GIS and Visualization 5" and "DocuSky Geographic Information Tools," and the base map uses modern base map Pioneer, and the "reference layer" was used to draw lines and arrow directions to visualize the "text layer" [32]. Through the common participation and the interaction between people, most of Taiwan's cultural assets can be accumulated into assets with rich cultural connotation. Although the research on cultural assets is becoming more and more popular, there are few studies on the development of related academic topics combined with databases and geographic information systems. In particular, the application of the map information system is an aspect that requires urgent consideration of deepening the related researches, and demonstrating Taiwan's multicultural characteristics and the overlapping nature.

\section{Results}

The cultural landscapes contained in databases such as the Taiwan People's Daily during the Japanese rule period or the Taiwan digital Library built by the National Taiwan Library provide information on spatial imagery $[33,34]$. The image conveys the message in which time and space were interwoven. The theme images were collected from the "Taiwan Old Photo Database" of the Digital Humanities Research Center of Taiwan University. This database collects digitized photos of Taiwan-related illustrations and "Taiwan Photo Posts" from the collected publications, generating more than 37,000 interpretation materials and providing subcategories of person names, place names, ages, and provenances. You can search for interpretation data and meanwhile download interpretation data and digital images within the academic fair use range. The indigenous cultural data contained in the database can also be compared with tribal field surveys. In applying these images, attention must be towards exploring the perspective of the author, painter, or photographer. On the other hand, it is appropriate to search for and interpret old photos such as the scenery of Taipei City that will strengthen the functions of cultural imagination and augmented reality.

In order to extensively collect background information on the subject of tourism and understand the historical trauma of Taiwan, the oral history or biographies and the National Human Rights Museum's oral documentaries related to political suppression were taken as references, by which we can imagine a series of tortures experienced by the victims. Some relatives of the victims converted the scars into words expressing their opaque and unspeakable emotions; however, in this vagueness, their depressed mood becomes more apparent. Field investigations or oral information reading can help understand the historical trauma in Taiwan. 


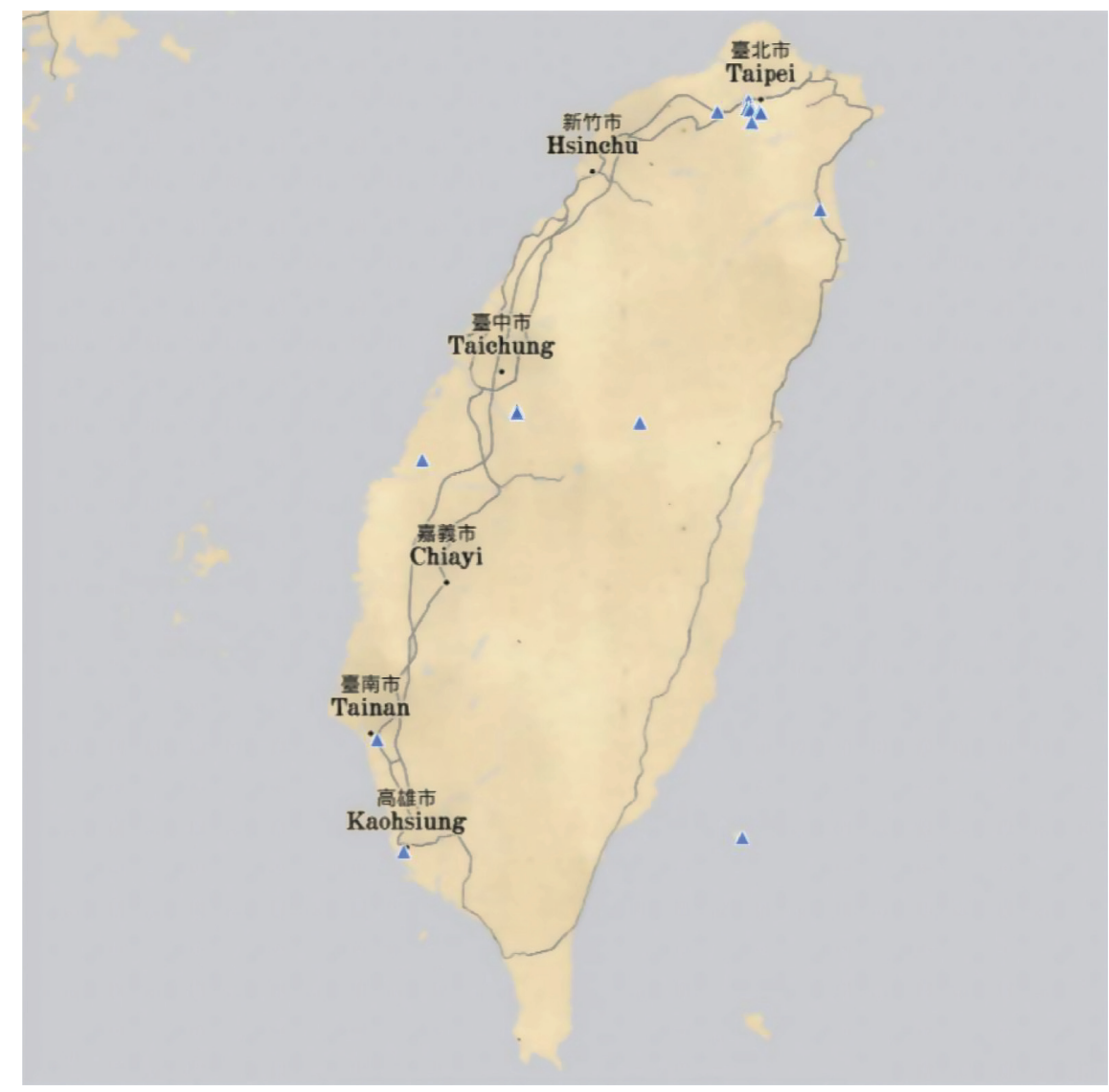

FIgUre 1: Map of human rights-themed cultural assets in Taiwan.

The GIS Special Center of the Humanities and Social Sciences Center of Academia Sinica uses Google base maps and combines the online query function of online maps to develop systems such as the Taiwan's century-old historical map [30]. As for the TGOS map collaboration platform, the API and Responsive Web Design platform of the Ministry of the Interior's Land Surveying and Mapping Center are used to integrate the government's open source base map resources and cross-platform interface. It not only allows the users to create themes themselves, but also edit or modify collaborative data with other people. Recently, the thought about combining the application of spatial information in the teaching of guided cultural landscapes came into mind. In order to make young students understand the relationship between the text and context of the times, they are first guided to read important texts and establish their ability for analysis and interpretation and in turn broaden students' international views from a local perspective. Cloud mapping and geographic information systems are also applied to develop thematic cultural tours. For example, stories based on the Taipei Human Rights Road combine texts, photos, and videos to present the context of places, events, issues, or geographic changes. Also, in conjunction with the course, students are led to a guided cultural tour, take photos or videos on the spot, and then use the Taiwan Fort map and the topographic layers, city street maps, aerial images, and satellite images of each period to make a comparison. An online collaborative Web GIS and a TGOS map collaboration platform were used to create the theme of the map material. Creating and sharing maps, scenes, layers and data, and story maps to combine Taiwan's historical maps were used. At the same time, mobile devices such as smartphones and tablets can also be used to combine historical positioning functions to browse historical map information.

Cultural memory is a method of preserving cultural continuity of a society, coupled with the collective knowledge passed down from generation to generation, and it is also a cultural behavior that helps with the cultural memory and helps future generations construct their own cultural identity. When monuments are set in a public open space with convenient transportation, it reminds the visitors of the impact of this event. In order to show the spatial location of human rightsthemed cultural assets, DocuGIS is used to draw Figure 1.

For example, the 228 Incident occurrences spot Monument, which is one of the sites reminiscent of the historical event, is located at the entrance of No. 185, Nanjing West Road, Taipei. As a spot for memory, it helps people to understand the historical context of the city and by deepening the interpretation of the historical event, it fully serves the cultural function of space. Another example is the former residence of Yin Hai-kuang, located at Alley 16, Lane 18, Wenzhou Street. Yin Hai-kuang moved from China to Taiwan in 1949, and then he translated and introduced Hayek's famous book "The Road to Slavery" to 




Figure 2: Taipei freedom route (A).

Taiwan. He upheld for life the spirit of "Would rather die than live in silence." He had taught at the Department of Philosophy of Taiwan University and wrote political commentaries for "Free China." He countered the prohibition of speech and thought with his pen and pointed out the errors of political affairs and offered advices in a philosophical way. Yin Hai-kuang reported customs of overseas countries in his travel writings, in order to criticize the party-state education in Taiwanese society at that time, and he analyzed the significance of freedom and democracy and published comments on cultural malady under Taiwan's totalitarian rule $[36,37]$. This former residence is a space metaphor under the authoritarian system of Taiwan, and it also signified the worldly way of the intellectuals under the oppression of the party-state system. Chen Wencheng Memorial Plaza in preparation is being set up on the campus of National Taiwan University in honor of the 31-year-old Chen Wencheng. The Chen Wencheng incident has made the international community aware of Kuomintang's covert actions and the whistleblowing habits of campus agents, and it was a real case of Taiwanese people's suffering in their struggle for democracy.

Considering that guided tours within two hours will be better for general tourists [31, 32], Taipei Freedom Route is planned: one is Chiang Weishui Memorial Park (Taiwan Cultural Association, Taiwan People's Party member monument $) \longrightarrow$ Taiwan New Culture Movement Memorial Hall (formerly Taipei Police Administrative Office) $\longrightarrow$ Blessed Imelda's School (Taiwan Culture Association), Ruins of Taiwan People's Party $\longrightarrow$ Old Site of Daan Hospital (Taiwan People News, Culture Publishing House) $\longrightarrow$ Tianma Tea House $\longrightarrow 228$ Incident occurrence spot Monument (Figure 2).

Another route in the vicinity is planned: National Taiwan University (Chen Wencheng Memorial Plaza, the April 6th Incident) $\longrightarrow$ Wisteria House $\longrightarrow$ Yin Hai-kuang Former Residence $\longrightarrow$ National Taiwan Normal University (Taipei High School Student Movement, the April 6th Incident) $\longrightarrow$ Taipei Prison Wall Remains (Figure 3).

The Taipei Criminal Office established a prison outside the east gate of Taipei City during the Japanese rule period. In 1904, the city walls were torn down and then converted into a western style prison [33]. The postwar Kuomintang government continued to use it until 1963, known as the Taipei Prison. This prison witnessed the Miaoli incident in 1913, the Xilaiyan incident in 1915, and the police incident in 1923. On June 19, 1945, 14 captured American pilots were charged for "bombing civilians" and thus executed inside the prison's North Gate; after Japan announced its surrender, 11 foreign pilots held in prison were released and returned to their hometowns. After the war, witnessing the 228 incidents and White Terror, it 


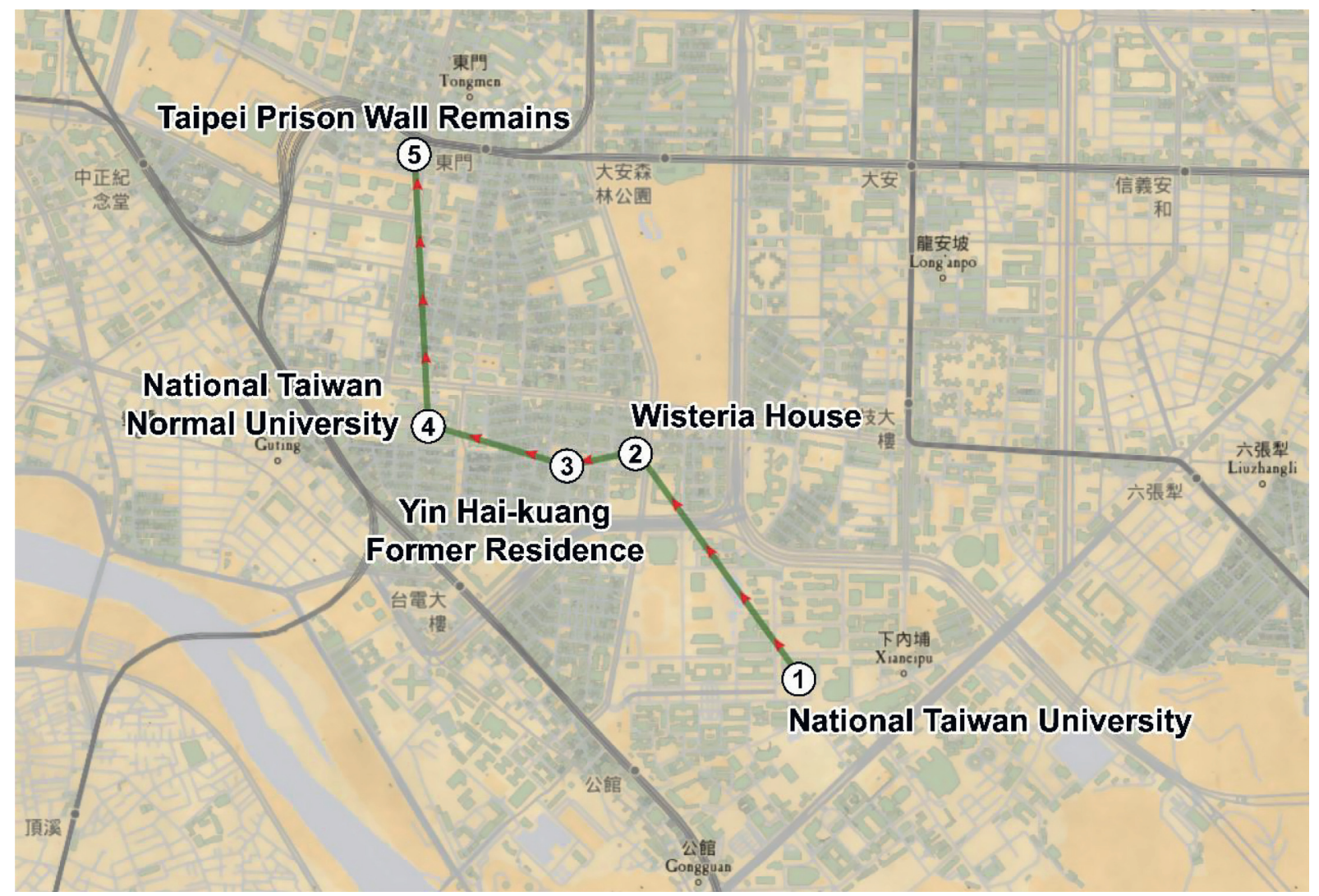

Figure 3: Taipei freedom route (B).

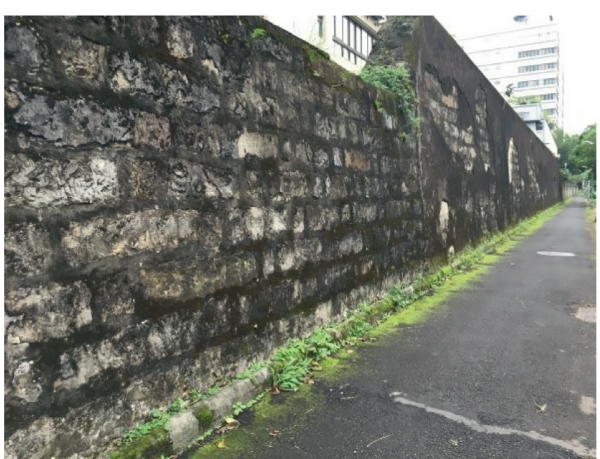

(a)

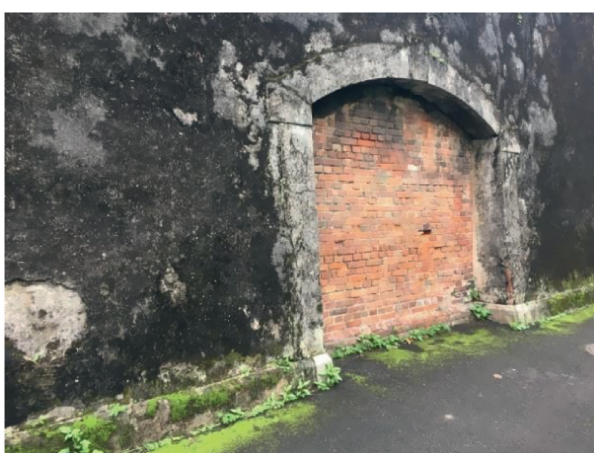

(b)

Figure 4: The remains of the Taipei prison wall. Source: Photos by Shuhui Lin; time: December 2, 2017; location: Lane 44, Section 2, Jinshan South Road.

turned out be an international-level historical spot as well as an important human rights event spot in Taiwan. Professor Zhuang once stated in the newspaper: "South Korea could preserve the Seodaemun Prison in Seoul and establish a historical and cultural park. Couldn't Taiwan?" [34] He urgently and actively participated in the social movement to establish the "Taipei Prison Memorial Cultural Park." However, only hundred meters long and about 4 meters high prison wall was left. One part of the walls was a stone arched door, and was intentionally sealed with red bricks. According to legends, it was the location for the family to get back the body of the executioner at that time. The wall stones were the old stones of Taipei City Wall, and they were andesite and Qillian quartz arenite mined from Neihu and Dazhi during the Qing Dynasty, and each stone was $30 \mathrm{~cm}$ thick. Figure 4 shows what these stones look like today:

There are many other scenes related to the theme of freedom, and it is advisable to plan cultural corridors in the future such as Zheng Nanrong Memorial Hall, Cai Ruiyue 


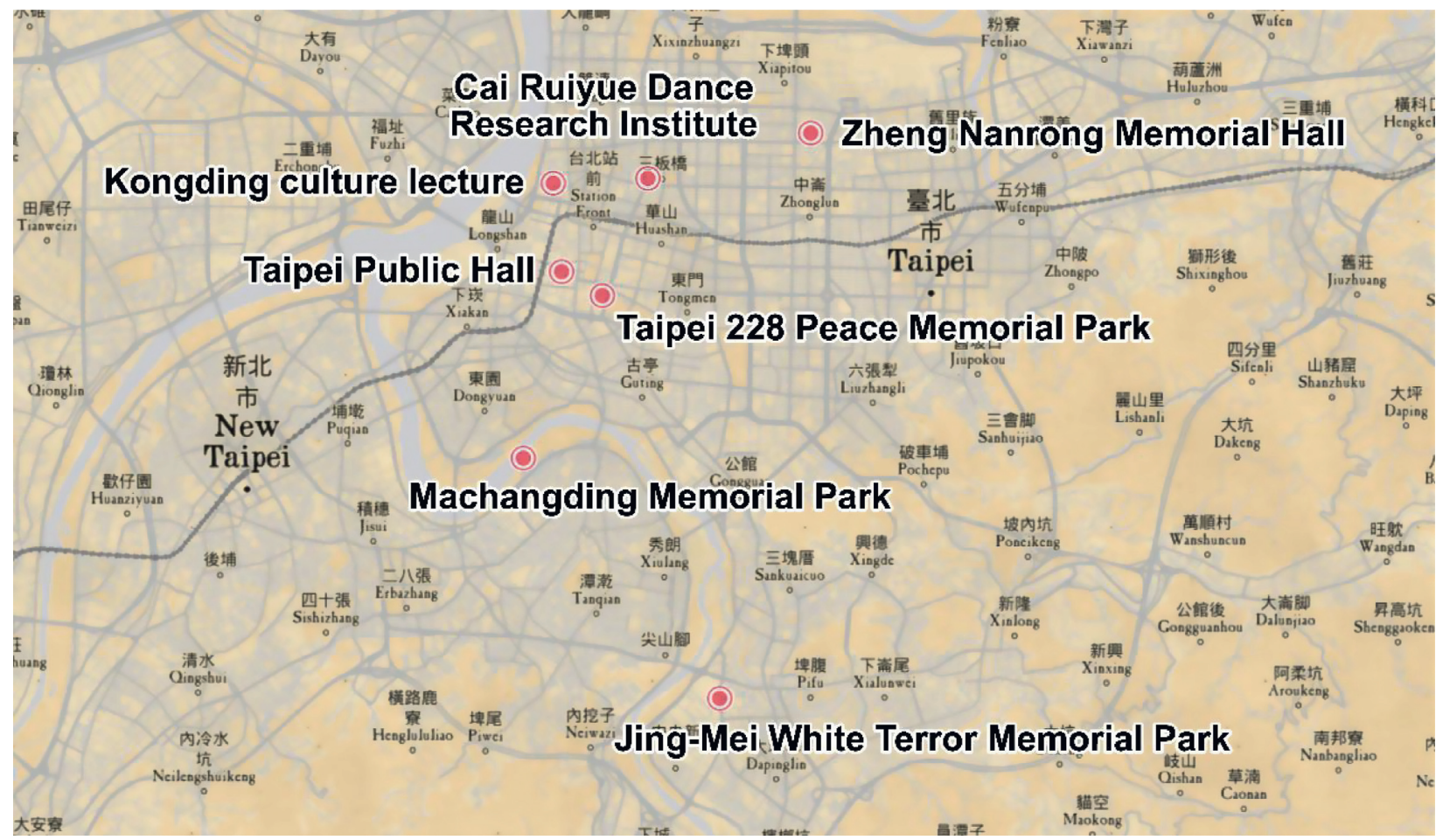

Figure 5: Human rights-themed cultural corridor in Taipei.

Dance Research Institute, Kongding culture lecture, Taipei Public Hall, Taipei 228 Peace Memorial Park, Machangding Memorial Park, and Jing-Mei White Terror Memorial Park, as shown in Figure 5.

Among them, the "Jing-Mei White Terror Memorial Park," one of the National Museum of Human Rights, was used as a detention center for the interrogation and detention of military, political, and public security cases from 1968 to the termination of the martial law. Its name was changed to "Jing-Mei White Terror Memorial Park" on December 10, 2007. This commemorative museum retains the historical building and space of the "Jing-Mei Military Detention Center," which represents the historical scene during the period of White Terror, and it functioned as a place for investigation and research, preservation of archives, display and publication, and promotion of human rights education [35]. In the past, since many real stories in the era of White Terror could not be revealed and transmitted, it was difficult to terminate tragedies and clarify misunderstandings. However, today it is possible to imagine the atmosphere of the martial law period by visiting important places known for prosecutions, trials, and executions due to political cases.

\section{Discussion and Conclusion}

By collecting information on Taiwan's cultural history, the multiple looks of the themed landscape are interpreted, guiding visitors to understand the context of Taiwan's cultural changes [36]. From Table 1, it is known that among cultural assets related to human rights themes, the number of historic sites is 19 , the most, followed by 14 historical buildings, and the era spans the Qing Dynasty, Japanese rule, and the postwar period [44, 45, 46]. The geographical distribution is mostly in Taipei area, and then less in the middle, and least in the south and east. Relevant historical events include ethnic issues between the Han and indigenous peoples during the Qing Dynasty, the anti-Japanese movement of Han and indigenous people during the Japanese rule period, and related human rights topics covered the postwar 228 event and human rights-related events during authoritarian rule, as well as monuments and historic buildings featuring human rights symbols such as prisons and courts and memorial characters.

The manuscript uses a digital humanities methodology to examine cultural assets and their place in the "human rights journey" in Taipei. In particular, the DocuSky tools can deal with a real-world topic. The findings include the maps that effectively convey visual information regarding human rights-themed cultural assets in Taiwan and two Taipei freedom routes inspired by a similar route in Boston, USA. I also suggest additional possible routes. The discussion provides additional examples of the interaction between cultural assets, especially within the DocuSky database. I hope to make contributions to the digital humanities community.

In addition, the application of databases in related fields can help collect data on the interactive relationship of Taiwan's multiculturalism. Looking back at the humanities research with the help of spatial information technology, it is discovered that its resources not only transcend the limits of institutions, national borders, domains, etc., but also further reveal the multiple contexts implicit in the data. Thus, a location-based service platform is setup to make a 
comprehensive analysis of cultural landscapes, provide a reference for planning tours to cultural landscapes, or enhance the humanism quality and emotional connection with the land, and promote the quality of cultural tourism for international tourists. For example, the Berlin Wall is the iconic scenery for tourists traveling to Germany, for it has a deep cultural significance. As for the Taipei Criminal Law Office, if the public can only see the remains of an old wall, how can they imagine its cultural implication. It is necessary to explain the story of the change of the Taipei Criminal Affairs Office, or through the public reports such as newspapers, readers' submissions and debates, or elites discussions about the process of planning ranging from the wall to the cultural park; it could then be made an example of cultural asset education. If combined with the stories of "Policy Incident," Lin Youchun, Jiang Weishui, Lai He, Wang Minchuan, and other human rights fighters who were detained at the Taipei Prison and interpreted the "Prison Literature" works, then the universal value will be manifested in this place. Tourism is a vital experience economy. Based on the value of Taiwan's human rights-themed cultural assets, the human rights journey in Taipei is guided to share Taiwan's happiness experience with the world. The application of innovative spatial information on the display of cultural assets is combined to reinterpret cultural understanding of the public and to give full play to the influence of humanities and public discourse on space practice.

\section{Data Availability}

The data used to support the findings of this study are available from the corresponding author upon request.

\section{Conflicts of Interest}

The author declares that there are no conflicts of interest.

\section{Acknowledgments}

This study was supported by the Ministry of Science and Technology of Taiwan (106-2410-H-003-116-MY3) and subsidized by the National Taiwan Normal University (NTNU), Taiwan.

\section{References}

[1] H.-Y. Tang, "Government support and authentication: the new tradition of city god folk festival in jinmen," Journal of Chinese Ritual, vol. 196, pp. 85-145, 2017.

[2] S.-H. Lin, "The Road to freedom: the universal value of Taipei's theme tourism," in Collection Of Taiwan's Cultural Path: Zhuang Wanshou and His Cultural Academia, pp. 152-158, Wu Sanlian Taiwan Historical Materials Foundation, Taipei, Taiwan, 2019.

[3] H. Lefebvre and Donald Nicholson-Smith trans, The Production of Space, pp. 1-9, Blackwell, Oxford, UK, 1991.

[4] C.-H. Wang, "Dialectics in multitude an exploration into/ beyond henri lefebvre's conceptual triad of production of space," Journal of Geographical Science, vol. 55, pp. 1-24, 2009.
[5] C.-H. Wang, "Cultural production of imaged cities and urban meanings: an analysis of the Taipei pictorial," City and Design, vol. 13/14, pp. 303-340, 2003.

[6] W.-C. Chuang and S.-C. Chiou, "The study of urban spatial image," Journal of Design Research, vol. 4, pp. 116-127, 2004.

[7] J.-G Lay, Y.-W Chen, G. H. Yeh, and C.-C. Huang, "Research on taiwan map perspectives," Journal of the Republic of China Map Society, vol. 14, pp. 31-42, 2004.

[8] S.-H. Lin and S. Wang, "Configuration of american metropolises' image during the period of Japanese rule: according to Taiwanese elites' analysis," Journal of Outdoor Recreation Study, vol. 30, no. 2, pp. 1-20, 2017.

[9] J.-G. Lay, Y.-W. Chen, and K.-H. Yap, "Mapping Taiwan from an alternative angle," Journal of Maps, vol. 7, no. 1, pp. 244-248, 2011.

[10] B. Y. H. Liao, "Re-examining human rights in taiwan," Taiwan Democracy Quarterly, vol. 5, no. 4, pp. 235-245, 2008.

[11] F. F.-T. Liao, "Irish human rights commission-interaction between peace and human rights," Tunghai University Law Review, vol. 31, pp. 1-67, 2009.

[12] M. Huang, "Taiwan's human rights journey," Taiwan Democracy Quarterly, vol. 5, no. 4, pp. 181-187, 2008.

[13] H.-Yu Huang, "Early formation and development of Taiwan's cultural heritage preservation act 1945-1984," Museum Quarterly, vol. 31, no. 4, pp. 5-32+i, 2017.

[14] Ministry of Culture, "Cultural assets preservation act," Chapter I Article 3 of General Provisions, 2016.

[15] Ministry of Culture, "Cultural assets preservation act," The Law on the Preservation of Cultural Assets, Chapter 2 Article 17 of Historic Sites, Historic Buildings, Memorial Buildings and Settlements, 2016.

[16] C.-F. Wei, "The development and limitation of human rights of Taiwan in post-martial law-compares with other Asian countries," Thought and Words: Journal of the Humanities and Social Science, vol. 46, no. 4, pp. 1-103, 2008.

[17] V. Y.-C. Weng, "Dialogue and bargain: mapping the international human rights law to understand the implementation of universal human rights conventions in taiwan," National Taiwan University Law Journal, vol. 46pp. 1115-1201, S, 2017.

[18] M. Zembylas, P. Charalambous, S. Lesta, and C. Charalambous, "Primary school teachers' understandings of human rights and human rights education (HRE) in Cyprus: an exploratory study," Human Rights Review, vol. 16, no. 2, pp. 161-182, 2015.

[19] J. A. Roy, "Labor rights are human rights," Working USA, vol. 3, no. 2, pp. 72-77, 1999.

[20] S.-H. Lin, "The memory of medical pilgrimage: Dr. Tsungming Tu's strategy of travel writings about Europe and the United States during the Japanese colonial period," Journal of Taiwan Literary Studies, vol. 21, pp. 1-38, 2015.

[21] Y.-c. Fan, "Caught between imperial medicine and colonial medicine: beriberi in colonial Taiwan," Taiwan Historical Research, vol. 25, no. 4, pp. 75-118, 2018.

[22] S.-H. Lin, "The application of the Taiwan history digital library (THDL) to the research of poetry and prose regarding customs in the earlier qing-governed period," in Digital $\mathrm{Hu}$ manities: New Approaches to Historical Studies, J. Hsiang, Ed., National Taiwan University Press, Taipei, Taiwan, 2011.

[23] S.-C. Lin, "The social constructing process of village placename and landmark place-name in the tai-ping of shuang-xi, new Taipei city: the application of taiwan history digital library (THDL)," Journal of Geographical Research, vol. 57, pp. 23-48, 2012. 
[24] D. Germano, "The relationship of buddhist studies and area studies: new perspectives from humanities computing," The Journal of Chinese Buddhist Studies, vol. 20, pp. 331-348, 2007.

[25] S.-P. Chen, Y.-M. Huang, J. Hsiang, H.-C. Tu, H.-I. Ho, and P.-Y. Chen, "Discovering land transaction relations from land deeds of Taiwan," Literary and Linguistic Computing, vol. 28, no. 2, pp. 257-270, 2013.

[26] J. Hsiang, S. P. Chen, H. I. Ho, and H. C. Tu, "Discovering relationships from imperial court documents of qing dynasty," International Journal of Humanities and Arts Computing, vol. 6, no. 1-2, pp. 22-41, 2012.

[27] A. Burdick, J. Drucker, P. Lunenfeld, T. Presner, and J. Schnapp, Eds., Digital Humanities, MIT Press, Boston, MA, USA, 2012.

[28] J. Hsiang, S.-P. Chen, and H.-C. Tu, "On building a full-text digital library of land deeds of Taiwan," in Digital Humanities, pp. 85-90, University of Maryland, College Park, MY, USA, 2009.

[29] S. P. Chen, J. Hsiang, H. C. Tu, and M. C. Wu, "On building a full-text digital library of historical documents," in Asian Digital Libraries. Looking Back 10 Years and Forging New Frontiers, D. Goh, T. Cao, I. Sølvberg, and E. Rasmussen, Eds., vol. 4822Springer, Lecture Notes in Computer Science, , pp. 49-60, Springer, 2007.

[30] T.-K. Ling, "Legislative yuan architecture analysis," Taiwan Natural Science, vol. 31, no. 2, pp. 18-23, 2012.

[31] T. Cresswell, Place: A Short Introduction, Wiley, NJ, USA, 2004.

[32] H.-C. Tu, "DocuSky: a platform for constructing and analyzing personal text databases," Journal of Digital Archives and Digital Humanities, vol. 2, pp. 71-90, 2013.

[33] S.-H. Lin, "Viewing landscapes to observe change: travel narratives in diaries during the japanese colonial period in Taiwan," Bulletin of Taiwanese Literature, vol. 32, pp. 23-52, 2018.

[34] P.-H. Hsu, "Common school graduates and Taiwanese society during the middle period of the Japanese occupation," Bulletin of Academia Historica, vol. 41, pp. 136-156, 2014.

[35] I.-C. Fan, H.-M. Liao, Ta-C. Chan, and L.-F. Chang, "Past, present and future of historical GIS in academia Sinica," Journal of Asian Network for GIS-Based Historical Studies, vol. 1, pp. 7-11, 2013.

[36] P.-H. Liao, "Print culture and the emergent public sphere in colonial Taiwan, 1895-1945," in Taiwan Under Japanese Colonial Rule, 1895-1945, D. D.-W. Wang and P.-H. Liao, Eds., History, Culture, Memory, Columbia University Press, New York, NY, USA, 2006.

[37] J. C.-h. Lin, "The personal is political: revisiting "English" and "Homeland” by reading shirley Geok-lin Lim's Hong Kong poetry," Translocal Chinese: East Asian Perspectives, vol. 13, no. 2, pp. 167-181, 2019.

[38] B. Curtis and C. Pajaczkowska, "Getting there: travel, time, and narrative," in Travelers' Tales: Narratives of Home and Displacement, G. Robertson and M. Mash, Eds., Routledge, London, UK, 1994.

[39] P. Barry, Beginning Theory: An Introduction to Literary and Cultural Theory, Manchester University Press, Manchester, UK, 2006.

[40] D. Botsman, Punishment and Power in the Making of Modern Japan, Princeton University Press, Princeton, NJ, USA, 2005.

[41] W.-S. Zhuang, Don't Let History Get Into the Black Prison, The Liberty Times, Taipei, Taiwan, 2014.
[42] C.-W. Lin, "Initial challenges and missions of the preparatory Office of the national human rights museum," Museology Quarterly, vol. 28, no. 3, pp. 111-126, 2014.

[43] C. Thompson, Travel Writing, Routledge, New York, NY, USA, 2011.

[44] S.-H. Lin, "The cultural cold war code of moving narration in today's world," Literature and Philosophy, vol. 32, pp. 433458, 2018.

[45] S.-H. Lin, "An analysis of narrative strategies in bordercrossing travel notes published by free China," The Journal of Taiwan Historical Association, vol. 20, pp. 116-152, 2016.

[46] Y.-J. Chen, "Dependence and competition: the dairy industry in Taiwan during the post-war and US-aid period (1945-1965)," Journal of Chinese Dietary Culture, vol. 13, no. 1, pp. 35-73, 2017. 